\title{
PRE-ISCHIATIC SILICONE IMPLANTS
}

\author{
By Alfredo Castro Sierra, M.D., ${ }^{\star}$ Antonio Lopez Pita, M.D. ${ }^{\star}$ and \\ Paloma Sanchez de Muniain, M.D. $\dagger$ \\ $\star$ Plastic Surgery Section, National Centre for the Rehabilitation of Paraplcgics; $\dagger$ Rehabilita- \\ tion Section, National Centre for the Rehabilitation of Paraplegics; Centro Nacional de \\ Rehabilitation de Paraplejicos, Toledo, Spain
}

\begin{abstract}
A silicone prosthesis for pre-ischiatic implantation is presented and described; it is used in operations of pressure sores in this area. It has been placed in nine cases, with satisfactory results.

The use of this prosthesis is recommended when the patient's psychic, social and economic conditions are precarious and when the fibrosis close to ulceration may be eliminated in the operation, but the transfer on the ischium of the adjacent musculature is problematic.

The author suggests to increase the use of this prosthesis prescription, implanting it as a usual restoration procedure and as a prophylactic method in special cases.
\end{abstract}

Key words: Silicone implants.

\section{Previous Report}

AMONGST all the critical weight-bearing areas in the pelvic girdle, in the sitting and decubitus positions, the most exigent and delicate is the ischiatic part. While the decubitus is possible in various positions, the sitting position has no alternative and implies always that the ischiatic protuberance should be resting on a few square centimetres of soft tissue (Castro Sierra, 1976).

This is the reason of the frequency of ischiatic pressure sores and the frequent recurrences found in these lesions.

This problem gets more serious, particularly in paraplegic patients and overall in the ones who have a professional activity and must spend a long time in the sitting position, exceeding the limited possibilities of weight-bearing that this area allows.

For the restoration of an ischiatic ulceration, besides an impeccable cutaneous cover, it is necessary to leave a well-padded ischiatic surface which guarantees a good weight-bearing in the sitting position.

The covering of the ischiatic area has been usually done with the adjacent musculature which, through an adequate mobilisation, besides covering the dead space left by the excision of the ulcer, is interposed between the bony surface and the cutaneous teguments (Dupuis, I973; Ger, 1976).

But, when operating very big or recurrent ischiatic ulcerations, the excision of the whole scar adjacent to the ulcer may leave an important pre-ischiatic area bare of tissues, making its restoration problematic. In other occasions, the muscular areas adjacent to the ulcer are in a bad condition and/or they are replaced by a cereous degenerated tissue, unfit either to devitalise it when rotating it or to be used as a weight-bearing surface.

This induced us to consider the silicone as an inclusion material in this weight-bearing area, in some occasions.

We made an ischiatic prosthesis (Fig. I) with a silicone lamina to support the 


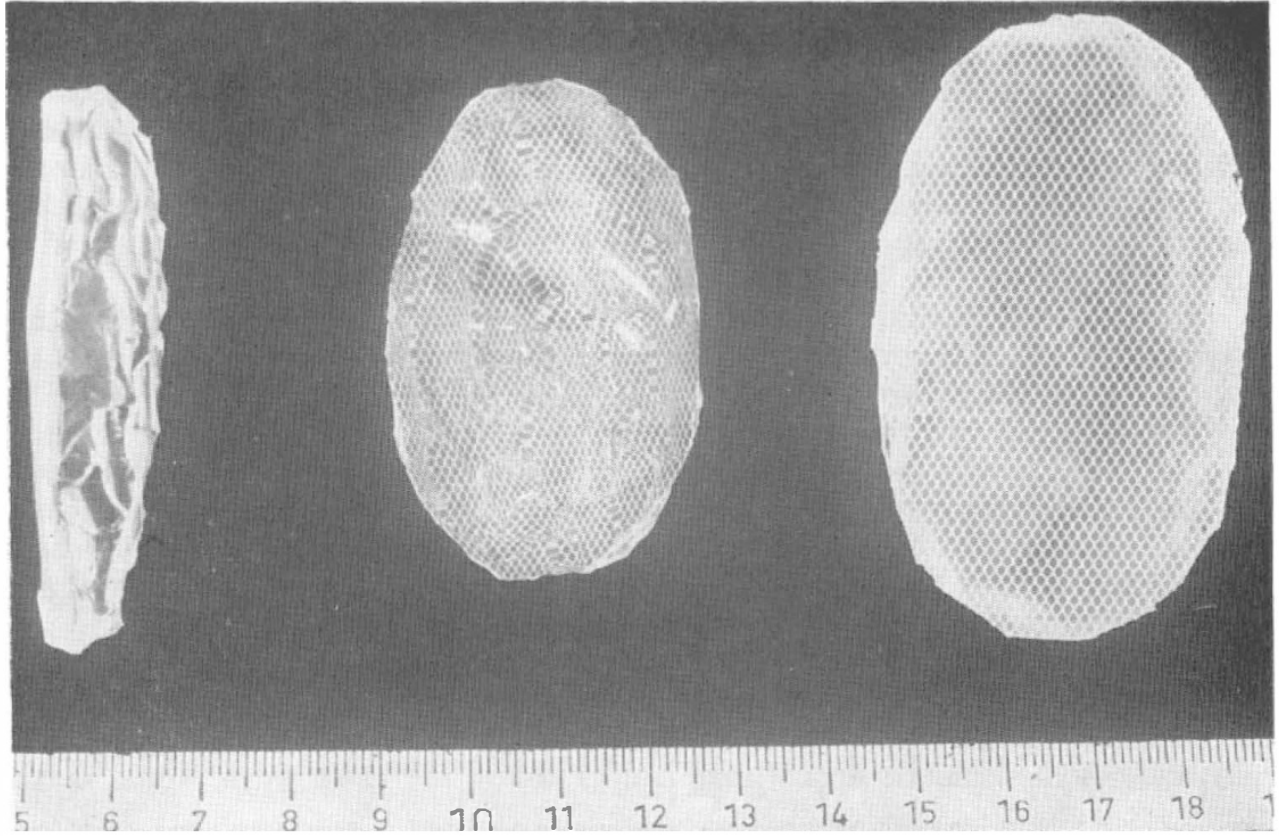

FIG. I

ischium, which had its lower portion excised during the operation. This lamina, although malleable, has a certain consistence and includes a nylon framework in order to fix it with suture stitches. We join a soft $2-\mathrm{cm}$ thick silicone material to this lamina, using implantable adhesive. All this is modelled at the required size, as it can be seen in Figure I. The prosthesis, thus conformed, is fitted to the ischiatic surface that is going to be padded. After excising any scar and fibrotic reaction in the area, and after doing a partial ischiectomy (Fig. 2), the prosthesis is sutured to the periostic rim exposed with nonabsorbable material (Fig. 3). Skin and subcutaneous cellular tissue are closed, adopting the usual drainage measures of these operations.

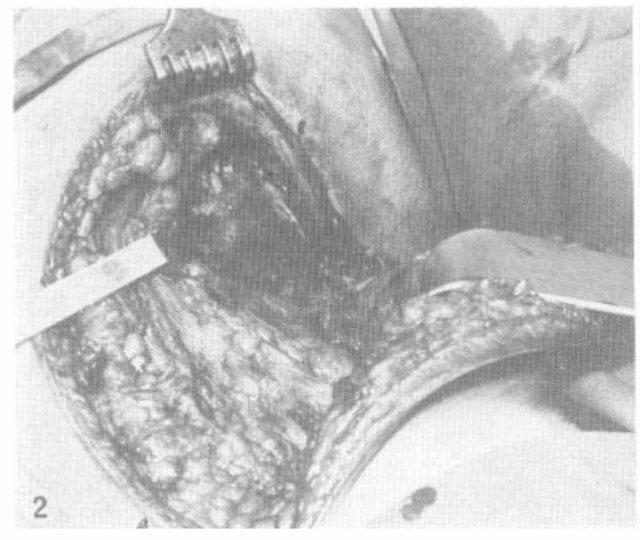

FIG. 2

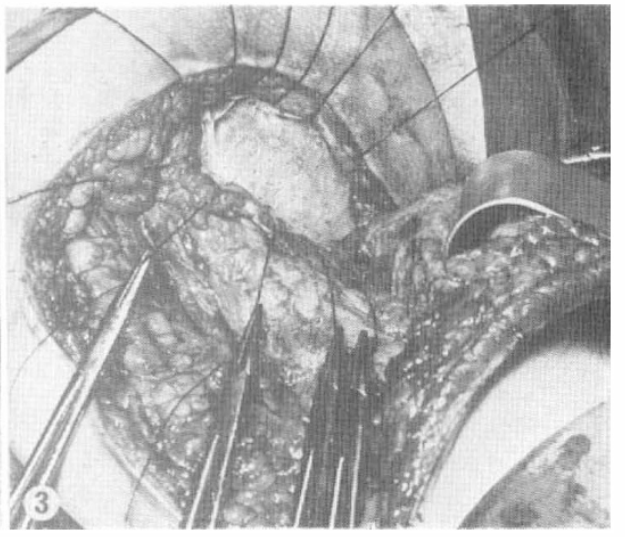

FIG. 3 
We have been using this procedure in nine cases, resuming the sitting position after 6 weeks. The longest follow-up is 24 months, and no severe complication was found in any of the cases. Two of them presented a small dehiscence in the medial side of the scar, that may be due to its extension towards the perineal area, easily macerated, caused by the previous ulceration. In both cases, the small dehiscence healed soon by second intention and it was not necessary to delay the beginning of the sitting position that was achieved, as we said already, after 6 weeks (Fig. 4).

In the sitting position of these cases we used, always and strictly, silicone or nylon-padded floatation cushions, which are traded through several brands. As yet, the results have been thoroughly satisfactory.

Through this preliminary communication, we suggest presently a possibility that we think worth taking into consideration. Up to now, in our cases, we recommended it for patients who presented one of the following two conditions:

(A) On the local point of view, when we were able to get a reception bed without any fibrosis and with a good quality, but the mobilisation of proximal muscular tissues was difficult.

(B) On the general point of view, when the patient presented factors which might affect negatively the late postoperative, such as precarious social and economic conditions and a weakened psyche, in order to secure the posterior intactness of the ischiatic area which, if operated in the usual ways, would make sure a recurrence.

Therefore we believe that we found a procedure that has given excellent results in spite of having been used in these cases of acknowledged bad prognosis. It may be prescribed as a standard procedure in the usual cases of ischiatic sores restoration; and even as a prophylactic measure, prior to the lesion,

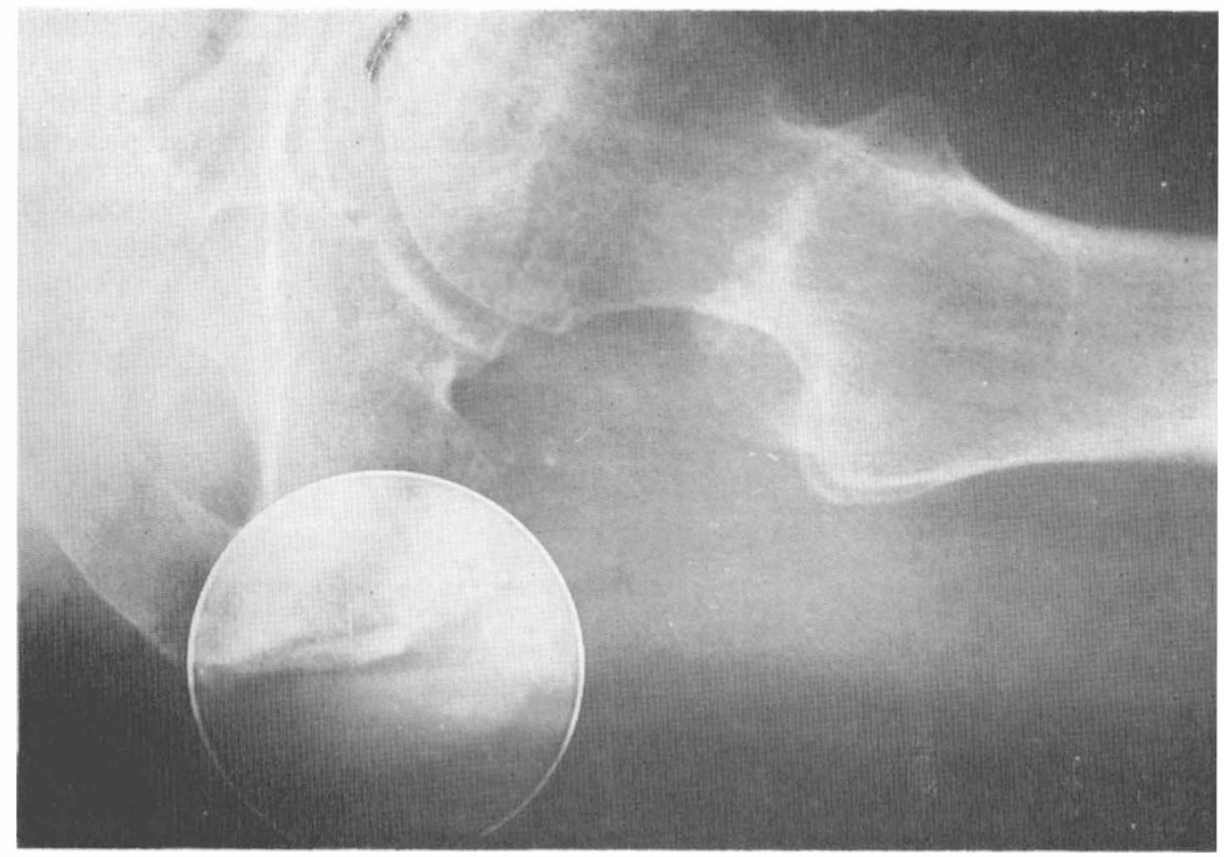

FIG. 4 
in case of particular susceptibility of the region, in extirpations of uninfected bursitis, and when the psychic, social and economic personal conditions do not guarantee that the patient will observe, when discharged from the hospital, the prophylactic measures against pressure sores.

We hope to present a further communication to give more indications of the ischiatic implant positioning, seconded by relevant cases.

\section{RÉSUMÉ}

On présente et décrit une implantation preisquiatique d'une prothèse de silicone, utilisée dans la réparation des ulcéres par pression sur cette zona.

Elle a été placée en neuf cas avec des résultats satisfaisants. L'utilisation de ces prothèses de silicone est prescrite en ces patients dont les conditions phychiques, sociales et économiques sont prêcaires et quand on élimine dans l'operation la fibrose qui entoure l'ulcération, mais c'est problematique la movilisation sur l'ischion de la musculature adjacent.

L'auteur suggére élargic on amplifier les indications de cette prothèse, en l'utilisant dans les habituelles réparations de ces ulcéres et comme mesure prophylactique en cas speciaux.

\section{ZUSAMMENFASSUNG}

Eine Prothese aus Silicone für das Ischium wird dargestellt und beschrieben. Sie wirl bei Decubitus-Operationen in diesem Bereich benützt. In neun Fällen ist sie mit erfreulichen Erfolgen angewandt worden.

Der Gebrauch dieser Prothese ist angezeigt, wenn die psychischen, sozialen und oeconomischen Bedingungen des Patienten preqär sind und wenn die Fibrose, die in der Gegend des Geschwür ist, in der Operation eliminiert werden kann. Der Transfer auf das Ischium ist wegen der Muskulatur schwierig.

Die Autoren schlagen die Anwendung der Prothese vor und wollen sie als normalen Prozess der Wiederherstellung bezeichnen und als prophylaktische Methode in besonderen Fällen.

\section{REFERENCES}

Castro Sierra, A. (I976). Evolucion clinica y reparacion quirurgica de las ulceras por presion. Rehabilitacion, 10, 107.

Castro Sierra, A. \& Almagro, P. L. (1976). Nuestra conducta profilactica en las ulceras por presion. Revista Quirurgica Española, 3, 394.

Dupuis, J. F., Debray, G. \& Vilain, R. (I973). Traitement des escarres ischiatiques par ischiectomie associee a une plastie musculaire. Annales de Cirurgie Plastique, 18, 27.

Ger, R. \& Levine, S. A. (I976). The management of decubitus ulcers by muscle transposition. Plastic and Reconstructive Surgery, 58, 4I9. 